\author{
Loyalitas Kreativitas \\ Aldi Masyarakat Kreatif
}

\title{
PELATIHAN BISNIS SYARIAH UNTUK SANTRIWAN SANTRIWATI DI YAYASAN ALKAMILAH BOJONGSARI, SAWANGAN, DEPOK
}

\author{
Evita Vibriana*, Setyanto, Endang Nurita, Ninik Anggraeni, Ahmad Akbar \\ Dosen Fakultas Ekonomi Universitas Pamulang \\ Email*: dosen0602@unpam.ac.id
}

\begin{abstract}
dosen01602@ unpam.ac.id, dosen01600@unpam.ac.id, dosen01972@unpam.ac.id, Dosen00976@unpam.ac, dosen01973@ unpam.ac.id
\end{abstract}

\begin{abstract}
ABSTRAK
Bisnis atau usaha secara syariah adalah segala sesuatu yang berkaitan dengan jual beli yang berlandaskan hukum syariah atau system Islam. Bisnis syariah sendiri berasal dari 2 (dua) kata, yakni bisnis dan syariah. Bisnis merupakan segala sesuatu yang berkaitan dengan jual beli atau berdagang, sementara syariah berarti sumber jalan yang lurus. Sementara secara istilah syariah artinya perundang-undangan yang diturunkan oleh Allah SubhanaWataala melalui Rasulullah Muhammad SAW untuk seluruh umat manusia baik yang menyangkut masalah ibadah, akhlak, makanan, minuman, pakaian maupun muamalah.

Kegiatan bisnis syariah bukan hanya kegiatan jual beli yang targetnya mendapatkan keuntungan, namun bisnis ini lebih mengarah kepada hukum Islam yang sesuai dengan Al Quran dan Hadist. Jadi bisnis ini dibatasi bagaimana cara mendapatkan keuntungan dan mengembangkannya dengan konsep halal dan haram. Jika halal dijalankan, namun jika haram maka ditinggalkan, sehingga bukan melulu keuntungan namun juga mendapatkan keridhoan dari Allah.

Dalam program kegiatan Pengabdian Kepada Masyarakat (PKM) kali ini sasarannya adalah para santriwan santriwati di yayasan Alkamilah dengan memberikan pengetahuan dan wawasan untuk mandiri dimasa depannya. Lembaga pendidikan diharapkan juga mampu mendorong mereka untuk menjadi wirausahawan-wirausahawan sejati khususnya para santri.

Berdasarkan permasalahan yang dihadapi anggota Yayasan Alkamilah, Bojongsari, Depok, melalui kegiatan pengabdian kepada masyarakat (PKM) para dosen dan mahasiswa dari Universitas Pamulang mencoba membantu memberikan pelatihan-pelatihan yang dibutuhkan Yayasan Alkamilah untuk para anak didiknya. Diharapkan dengan pelatihan bisnis syariah ini dapat membantu menambah ilmu pengetahuan, meningkatkan wawasan dan ketrampilan para santri di yayasan tersebut.
\end{abstract}

Kata kunci: Bisnis,Wirausaha, Halal, Berkah 


\section{Loyalitas Kreativitas \\ Aldi Masyarakat Kreatif}

P-ISSN 2722-2101, E-ISSN 2722-4201

Program Studi Ekonomi Manajemen Universitas Pamulang

Jurnal LOKABMAS Kreatif Vol. 01, No. 03, Hal. 87-96

Email:jurnalkreatif.manajemen@gmail.com

\begin{abstract}
Business or business in sharia is everything related to buying and selling based on sharia law or the Islamic system. Islamic business itself comes from 2 (two) words, namely business and sharia. Business is everything related to buying and selling or trading, while sharia means the source of the straight path. Meanwhile, in terms of sharia, it means legislation that was sent down by Allah SubhanaWataala through Rasulullah Muhammad SAW for all mankind, both concerning matters of worship, morals, food, drink, clothing and muamalah

Sharia business activities are not just buying and selling activities whose target is to get profit, but this business is more directed towards Islamic law which is in accordance with the Al Quran and Hadith. So this business is limited on how to get profit and develop it with the concept of halal and haram. If it is lawful it is practiced, if it is haram then it is abandoned, so that it is not only profit but also gets the pleasure of God.
\end{abstract}

In the Community Service program (PKM) this time the target is santriwan santriwati at the Alkamilah foundation by providing knowledge and insights to be independent in the future. Educational institutions are also expected to be able to encourage them to become true entrepreneurs, especially students.

Based on the problems faced by members of the Alkamilah Foundation, Bojongsari, Depok, through community service activities (PKM) lecturers and students from Pamulang University have tried to help provide the training needed by the Alkamilah Foundation for their students. It is hoped that this sharia business training can help increase knowledge, increase the insight and skills of the students at the foundation.

\title{
Keywords: Business, Entrepreneurship, Halal, Blessing
}

\section{PENDAHULUAN}

Konsep bisnis syariah bisnis atau berwirausaha syariah mereka ditekankan pada kejujuran, ikhlas dan semata-mata hanya untuk mencari keridhaan Allah, maka seluruh bentuk transaksinya insya Allah menjadi ibadah di hadapan Allah SWT. Ini akan menjadi bibit dan modal dasar baginya untuk tumbuh menjadi bisnis yang besar, yang memiliki spiritual brand, yang memiliki kharisma, keunggulan, dan keunikan yang tak tertandingi. Dalam spiritual marketing, hal-hal yang sekiranya dapat merugikan konsumen akan berusaha untuk dihindarkan.

Yayasan Al-Kamilah adalah Yayasan yatim piatu dan dhuafa yang didirikan oleh Ustad Ahmad Badruddin. Dapat menampung didalam asrama sebanyak 30 (Tiga Puluh) anak asuh dari Jabotabek. Sedangkan untuk keseluruhan yang berada di luar mencapai 50 (Lima Puluh) anak. Sehingga total yang diasuh yayasannya mencapai 80 (Delapan Puluh) anak dari Jabodetabek, maupun Kebumen, Purwakarta, Banten dan lainnya. Pernah dikunjungi oleh 33 (Tiga Puluh Tiga) Negara. Serta 
Loyalitas Kreativitas

Aldi Masyarakat Kreatif banyak prestasi yang telah diraihnya seperti juara pertama keteladanan seJawa barat. Sehingga menjadi kebanggaan kota Depok karena kerap mengukir prestasi gemilang dikancah provinsi maupun nasional.

Kami selain dosen Prodi Akuntansi Universitas Pamulang juga berperan dalam masyarakat melalui kegiatan Pengabdian Kepada Masyarakat (PKM), melalui pelatihan bisnis syariah sejak usia dini di Yayasan Alkamilah untuk diterapkan dalam kehidupan sehari-hari bagi masyarakat khususnya santriwan santriwati, sebagai wujud Tri Darma Perguruan Tinggi, Fakultas Ekonomi S1 UNPAM , maka akan menyelenggarakan Pengabdian Kepada Masyarakat (PKM) dengan judul "Pelatihan Bisnis Syariah Untuk Santriwan Santriwati di Yayasan Alkamilah Bojongsari, Sawangan, Depok". Beberapa langkah yang ditempuh sebagai metode untuk melaksanakan solusi terhadap permasalahan yang dihadapi yayasan akan dilakukan dengan beberapa hal sebagai berikut : 1 . Sosialisasi Program; 2. Koordinasi; 3. Pelaksanaan Program; 4. Evaluasi Program.

\section{RUMUSAN MASALAH}

1. Memberikan pengetahuan tentang bisnis syariah.

2. Memberikan wawasan pada para santriawan santriawan menjadi wirausahawanwirausahawan dimasa depannya

3. Memberikan motivasi tentang peluang-peluang bisnis syariah pada Yayasan Alkamilah Bojongsari, Sawangan, Depok.

\section{TUJUAN PELAKSANAAN}

$\begin{array}{lcr}\text { Tujuan } & \text { kegiatan } & \text { pengabdian } \\ \text { masyarakat } & \text { ini } & \text { adalah untuk }\end{array}$ memberikan pengetahuan, wawasan, dan ketrampilan para santri di Yayasan Alkamilah. Secara rinci tujuan kegiatan ini diantaranya untuk :

1. Memberikan ilmu pengetahuan mengenai teori-teori bisnis syariah sesuai ketentuan bisnis atau usaha sesuai ajaran Agama Islam.

2. Memberikan wawasan kepada Santriwan Santriwati di yayasan Alkamilah tentang bagaimana mereka menjadi pada wirausaha sejati dimasa depan.

3. Memberikan motivasi dengan memberikan contoh bisnisbisnis syariah untuk dikembangkan pengetahuan tentang bisnis syariah. Bagaimana mencari peluangpeluang bisnis syariah.

\section{TINJAUAN PUSTAKA}

\section{Pengertian Bisnis}

Bisnis merupakan suatu aktivitas yang dilakukan oleh seseorang atau sekelompok orang untuk menyediakan barang atau jasa dengan tujuan untuk memperoleh keuntungan. Dalam menjalankan bisnis, tentunya ada sebuah proses, atau biasa dikenal dengan proses bisnis. Proses bisnis terbagi dua, pertama Proses Bisnis Syariah, dan kedua Proses Bisnis Konvensional.

Proses bisnis syariah yaitu proses bisnis yang berlandaskan prinsip-prinsip Islam dan terikat pada moral dan etika sesuai ajaran Al-Quran dan Hadist. Sedangkan proses bisnis konvensional yaitu proses bisnis yang berlandaskan dasar pemikiran dan kemampuan manusia. Konsep Islam tidak menyangkal bahwa kepentingan pribadi merupakan salah satu penentu perilaku manusia, namun mengenai 
Loyalitas Kreativitas

Aldi Masyarakat Kreatif
P-ISSN 2722-2101, E-ISSN 2722-4201

Program Studi Ekonomi Manajemen Universitas Pamulang

Jurnal LOKABMAS Kreatif Vol. 01, No. 03, Hal. 87-96

Email:jurnalkreatif.manajemen@gmail.com pribadi ini dikendalikan dengan tanggung jawab sosial, serta moralitas secara umum. Paradigma yang digunakan dalam ekonomi Islam selain tujuan ekonomi itu sendiri adalah keadilan sosial (tidak semata hanya memaksimalkan kekayaan dan konsumsi, melainkan juga menekankan perlunya keseimbangan, kebutuhan material dan spiritual).

Pondasi Dasar Aqidah adalah suatu ideology samawi yang membentuk paradigma dasar bahwa alam semesta diciptakan oleh Allah Yang Maha Esa sebagai sarana hidup bagi seluruh umat manusia untuk mencapai kesejahteraan secara material dan spiritual. Menimbulkan kesadaran bahwa setiap aktivitas bisnis yang dijalankan oleh manusia sebagai hamba Allah (mahluk ciptaannya) memiliki akuntabilitas ketuhanan sehingga menumbuhkan integritas yang sejalan dengan prinsip GCG (Good Corporate Governance) dan market discipline. Akuntabilitas ketuhanan yaitu : dapat dipertanggungjawabkan

(responsibility), dapat dipertanyakan (answerability), dapat dipersalahkan (blameworthiness) dan mempunyai ketidakbebasan (liability).

Di bawah ini adalah pondasi pendukung bisnis atau usaha :

a. Syariah

Merupakan ketentuan hukum Islam yang mengatur aktivitas umat manusia yang berisi perintah dan larangan, baik yang menyangkut hubungan interaksi vertical dengan Tuhan maupun interaksi horizontal dengan sesama makhluk. Dalam perpektif bisnis berupa kaidahkaidah hukum muamalah dibidang ekonomi atau bisnis prinsip syariah yang berlaku umum dalam kegiatan muamalah akan mengikat secara hukum bagi semua pelaku dan stakeholder. Interpretasi syariah didasari oleh konsep aqidah yang baik. Syariah akan membimbing aktivitas bisnis sehingga selalu sesuai dengan tuntunan agama (jalan keselamatan).

b. Akhlaq

Merupakan norma dan etika yang berisi nilai-nilai moral dalam interaksi sesama makhluk harmonis. Akhlaq membimbing aktivitas bisnis senantiasa mengedepankan kebaikan sebagai cara mencapai tujuan Interpretasi akhlaq juga didasari oleh konsep mengedepankan kebaikan sebagai cara mencapai tujuan Interpretasi akhlaq juga persaudaraan dalam menata interaksi sosial yang diarahkan pada harmonisasi kepentingan individu dengan tujuan kemanfaatan secara umum dengan semangat saling tolong menolong. Ukhuwah dalam bisnis dilakukan melalui proses taáruf (saling mengenal), tafahum (saling memahami, taáwun (saling menolong), takaful (saling menjamin dan tahaluf (saling beraliansi). Ukhuwah meletakkan tata hubungan bisnis dalam konteks kebersamaan universal untuk mencapai kesuksesan atau kemenangan bersama. Mengandung Prinsip Keadilan, keadilan dalam Islam adalah menempatkan sesuatu hanya pada tempatnya dan memberikan sesuatu hanya pada yang berhak serta memperlakukan sesuatu sesuai posisinya. Implementasi keadilan dalam bisnis syariah: La Maysir, artinya tidak spekulasi atau gambling; La Asusila, artinya tidak melanggar kesusilaan; La Gharar, artinya tidak 
Loyalitas Kreativitas

Aldi Masyarakat Kreatif
P-ISSN 2722-2101, E-ISSN 2722-4201

Program Studi Ekonomi Manajemen Universitas Pamulang

Jurnal LOKABMAS Kreatif Vol. 01, No. 03, Hal. 87-96

Email:jurnalkreatif.manajemen@gmail.com manipulasi atau transparan saling ridha (an taradhin) dan saling menguntungkan (ta'awun); La Haram artinya objek dan proyek bisnis tidak haram halalan thayyiban; La Dzulm, artinya tidak menimbulkan kemudharatan dan kedzaliman; La Ihtikar, artinya tidak melakukan penimbunan dan monopolistik; La Riba, artinya tidak menggunakan sistem bunga.

Berikut ini adalah prinsipprinsip bisnis syariah yang harus diterapkan:

1. Prinsip Kemaslahatan

Dalam istilah para ulama, maslahat adalah : mengambil manfaat dan menolak bahaya (kerusakan). Hakekat kemaslahatan dalam Islam adalah segala bentuk kebaikan dan manfaat yang berdimensi integral duniawi dan ukhrawi, material dan spiritual, serta individual dan kolektif. Sesuatu dipandang Islam bermaslahat jika memenuhi dua unsur yakni kepatuhan syariah (halalan) dan bermanfaat serta membawa kebaikan (thayiban) bagi semua aspek secara integral yang tidak menimbulkan mudharat dan merugikan pada salah satu aspek. Secara luas, maslahat ditujukan pada pemenuhan visi kemaslahatan yang tercakup dalam maqasid syariah yang terdiri dari konsep perlindungan terhadap keimanan dan ketakwaan (dien), keturunan (nasl), jiwa dan keselamatan (nafs), harta benda (maal) dan rasionalitas ('aql).

2. Prinsip Keseimbangan

Konsep syariah menempatkan aspek keseimbangan sebagai salah satu dasar dalam pembangunan sistem ekonomi. Konsep keseimbangan dalam konsep syariah meliputi berbagai segi yang antara lain meliputi keseimbangan pembangunan material dan spiritual, pengembangan sektor keuangan dan sektor riil, bisnis dan social, dan eksploitasi dan konservasi. Pembangunan bisnis syariah tidak hanya ditujukan untuk pengembangan sektor-sektor korporasi namun juga pengembangan sektor usaha kecil dan mikro yang terkadang luput dari upayaupaya pengembangan sektor ekonomi secara keseluruhan.

Dalam berbisnis syariah harus menerapkan empat prinsip yaitu prinsip jual beli (Ba'í), Prinsip Sewa (Ijarah), Prinsip Bagi Hasil (Syirkah), Prinsip Wadiah (titipan), Prinsip Mudharabah.

1. Prinsip Jual Beli (Ba'i) :

Prinsip jual beli dilaksanakan sehubungan dengan adanya perpindahan kepemilikan barang atau benda (transfer of property). Prinsip ini pembagian keuntungannya ditentukan didepan dan menjadi bagian harga atas barang yang dijual. Prinsip jual beli ini dibedakan berdasarkan bentuk pembayaran dan waktu penyerahan barang seperti :

\section{a. Murabahah}

Akad dalam jual beli atas barang tertentu di mana penjual menyebutkan dengan jelas barang yang diperjualbelikan. 
Loyalitas Kreativitas

Aldi Masyarakat Kreatif
P-ISSN 2722-2101, E-ISSN 2722-4201

Program Studi Ekonomi Manajemen Universitas Pamulang

Jurnal LOKABMAS Kreatif Vol. 01, No. 03, Hal. 87-96

Email:jurnalkreatif.manajemen@gmail.com pembelia

kepada

harga

barang laba atau keuntungan dalam jumlah tertentu. Dalam konsep murabahah penjual harus memberitahu harga produk yang dibeli dan menentukan suatu tingkat keuntungan sebagai tambahannya.

Murabahan sendiri bisa diakukan untuk pembelian secara pemesanan. Transaksi jual beli barang secara pesanan. Di mana penjual akan menyerahkan barang dagangannya di kemudian hari sementara pembeli melakukan pembayaran pada saat akad telah disepakati yang telah memenuhi syarat-syarat tertentu. Maksudnya dari transaksi ini adalah penyerahan barang $\mathrm{du}$ kemudian bersamaan dengan pembayaran tunai di muka. Jadi harga memang telah ditetapkan di awal waktu walau penyerahan barangnya baru bisa dilakukan di kemudian hari. Transaksinya dibolehkan namun dengan syarat pembelian hasil produksi harus diketahui spesifikasinya secara jelas seperti jenis, macam, ukuran, mutu dan jumlahnya. Apabila hasil produksi yang diterima cacat dan tidak sesuai dengan akad maka produsen harus bertanggung jawab dengan cara mengembalikan dana yang telah diterimanya atau mengganti barang yang sesuai dengan pesanan.

\section{b. Istishna}

Suatu akad transaksi yang terjalin antara pemesan sebagai pihak pertama dengan seorang produsen suatu barang sesuai yang diinginkan oleh pihak pertama dengan harga yang telah disepakati keduanya. Syarat-syarat objek yang akad menurut Fatwa DSN MUI yaitu : Harus bisa dijelaskan spesifikasinya; Penyerahannya dilakukan kemudian; Waktu dan tempat penyerahan barang harus ditetapkan berdasarkan

kesepakatan; Pembeli tidak boleh menjual barang sebelum menerimanya; Tidak boleh menukar barang kecuali barang sejenis sesuai dengan kesepakatan; Memerlukan proses pembuatan setelah akad disepakati; Barang yang diserahkan harus sesuai 
Loyalitas Kreativitas

Aldi Masyarakat Kreatif
P-ISSN 2722-2101, E-ISSN 2722-4201

Program Studi Ekonomi Manajemen Universitas Pamulang

Jurnal LOKABMAS Kreatif Vol. 01, No. 03, Hal. 87-96

Email:jurnalkreatif.manajemen@gmail.com dengan spesifikasi

pemesan bukan barang.

2. Prinsip Sewa (Ijarah)

Transaksi Ijarah ada dua macam yaitu ijarah dengan objek transaksi berupa benda tertentu semisalnya menyewakan rumah, kos-kosan, rental kendaraan. Kedua ijarah transaksi pekerjaan tertentu misalnya memperkerjakan orang untuk membangun rumah, mencangkul kebun dan lain-lain. Meskipun hanya sewa menyewa namun bisnis syariah ini juga harus memiliki persyaratan tertentu seperti: Pelaku usahanya adalah orang yang sudah baligh dan berakal; adanya kejelasan jasa atau manfaat uang dibeli misalnya menempati suatu rumah atau pelayanan yang diberikan oleh pembantu rumah tangga.

\section{Prinsip Bagi Hasil (Syirkah)}

Merupakan akad kerja sama antara dua pihak atau lebih dalam suatu usaha, dimana masing-masing pihak memberikan kontribusi modal dengan kesepakatan bahwa keuntungan dan risiko yang akan diperoleh ditanggung bersama sesuai dengan kesepakatan. Syirkah sendiri terdiri dari enam macam namun secara garis besarnya syirkah bisa dibedakan menjadi dua jenis yakni Syirkah Amlak dan Syirkah Uqud. Syirkah Amlak yakni kerja sama antara dua orang atau lebih dalam kepemilikan suatu barang.
Sementara Syirkah Uqud yakni perserikatan antara dua pihak atau lebih dalam hal usaha, modal dan keuntungan.

\section{METODE PELAKSANAAN}

Dalam pelaksanaan kegiatan ini metode yang kita ambil adalah dengan metode ceramah, diskusi dan Tanya jawab. Pada sesi ceramah membahas mengenai Wirausaha ialah seseorang yang menjalankan suatu usaha untuk memperoleh laba dimana dalam prosedurnya dapat membentuk sesuatu yang produktif dan mempunyai faedah lebih. Wirausahawan atau seseorang wirausaha juga harus mempunyai perilaku yang khusus dan menyatu pada diri sendiri misalnya keyakinan diri, sehingga bisa mendirikan seseorang untuk mempunyai keinginan lebih untuk mencari akal sesuatu yang lebih dahulu belum sempat dijalankan. Selanjutnya gambaran bagaimana menjadi seorang pengusaha atau entrepreneur untuk memotivasi para santri kedepannya berwirausaha. Dengan berwirausaha mereka yang akan menciptakan dan membuka lapangan kerja di masyarakat. Wirausaha adalah sebagai bagian utama dari soko guru perekonomian Indonesia dan mengurangi jumlah pengangguran serta pada kesempatan tersebut juga disebutkan bahwa berwirausaha memupuk jiwa kemandirian bagi masyarakat. Pada sesi diskusi, para santri diberikan pemahaman tentang teori tentang bisnis syariah, yaitu bisnis yang dilakukan sesuai ajaran agama Islam. Program pelatihan yang didukung oleh para dosen akuntansi dan dosen manajemen Universitas Pamulang. Pada sesi tanya jawab, membahas bagaimana mencari peluang-peluang bisnis yang ada 
diluaran sesuai kenyataan dimasyarakat dengan mengikuti perkembangan jaman seperti bisnis online saat ini yang sedang berkembang pesat serta memberikan contoh orang-orang muda yang sukses saat ini dengan berwirausaha di Indonesia.

\section{PRA KEGIATAN}

\begin{tabular}{ccc}
\multicolumn{2}{c}{ Sebelum acara } & Pengabdian \\
Masyarakat & dilakukan & tim Dosen \\
Pengabdian & Kepada & Masyarakat
\end{tabular}
UNPAM melakukan beberapa agenda antara lain dapat digambarkan dalam alur berikut:

\section{Tahap Persiapan}

a. Kegiatan Observasi dan Perizinan Observasi dilakukan dengan melakukan survey pada lokasi yang akan dijadikan kegiatan Pengabdian Kepada Masyarakat (PKM) yakni di Yayasan Alkamilah Depok. Survey dilakukan 3 (Tiga) kali untuk menentukan titik yang tepat yang akan dijadikan sebagai point kegiatan. Dalam tahapan perizinan para dosen berkordinasi dengan pihak terkait, seperti: pimpinan Yayasan Alkamilah dan pengurus Yayasan tersebut.

b. Penyusunan RAB

Rencana Anggaran dan Belanja dipersiapkan dalam hal pembelian belanja bahan seperti: Honor narasumber, cinderamata atau plakat, konsumsi, sertifikat, materi, pembuatan jurnal dan door prize serta beberapa peralatan lain nya yaitu: tempat pelatihan, sound system, laptop dan LCD proyektor.

c. Pengajuan Proposal

Proposak kegiatan PKM diajukan pada tanggal 22 Maret 2020 dan setelah melalui proses review,

\author{
disetujui oleh Ketua LPPM \\ Bapak Ali Madinsyah pada \\ tanggal 9 April 2020.
}

2. Tahap Implementasi/ pelaksanaan kegiatan

Kegiatan Pengabdian Kepada

Masyarakat (PKM) dilaksanakan di

Ruangan pertemuan Yayasan

Alkamilah Depok pada tanggal 26,27 dan 28 Juni 2020

\section{HASIL DAN PEMBAHASAN}

Hasil yang telah dicapai berdasarkan pelaksanaan kegiatan Pengabdian Kepada Masyarakat (PKM) yang telah dilaksanakan dapat identifikasi sebagai berikut:

1. Memberikan pembekalan materi kepada para peserta PKM yang terdiri dari para guru yayasan dan Santriwan Santriwati Yayasan AlKamilah, Bojongsari, Sawangan, Depok, Jawa Barat.

2. Materi yang pertama diberikan oleh narasumber adalah tentang Bisnis Syariah, Yaitu pengetahuan tentang bagaimana usaha sesuai ajaran agama Islam, tentunya usaha dengan halal. Para Santri diberikan motivasi menjadi pribadi yang mandiri dengan berwirausaha, sehingga menjadi sosok generasi yang selalu optimis menatap masa depan.

3. Dilakukan tanya jawab tentang bisnis syariah yang sudah disampaikan dengan memberikan kuis dan permainan-permainan dengan memberikan pertanyaanpertanyaan dengan memberikan hadiah kuis, baik yang bertanya maupun yang menjawab. Tujuannya adalah untuk menguji pemahaman peserta mengenai materi yang sudah diberikan. 


\section{KESIMPULAN DAN SARAN Kesimpulan}

Kegiatan

pelaksanaan

Pengabdian Kepada Masyarakat (PKM) Kepada Santriwan Santriwati disebuah yayasan sangat dibutuhkan, dengan memberikan Pelatihan Binis Syariah wawasan Santri bertambah luas untuk bekal masa depan mereka.

Pengabdian

selanjutnya pendampingan kepada santriwan santriwati dalam rangka mewujudkan santri yang mandiri, dengan memberikan materi-materi pelatihan lainnya yang dibutuhkan.

Kegiatan PKM ini telah memberikan kontribusi kepada para Santri dengan memberikan bisnis syariah itu dan nantinya diterapkan. Berdasarkan pelaksanaan kegiatan Pengabdian Kepada Masyarakat yang dilaksanakan di Yayasan Alkamilah, Bojongsari, Sawangan, Depok pada hari Sabtu, Minggu dan Senin, Tanggal 26,27 dan 28 Juni 2020, dapat ditarik kesimpulan bahwa secara umum kegiatan pengabdian kepada masyarakat dapat terlaksana dengan baik dan mendapat sambutan dan dukungan dari pihak Yayasan Alkamilah dari segi tempat, sarana prasarana dan akomodasi, serta antusias para peserta yaitu Santriwan Satriwati sehingga dapat bermanfaat bagi mereka untuk masa depannya.

\section{Saran}

Berdasarkan kegiatan yang sudah terlaksana beberapa saran yang dapat kami sampaikan kedepannya adalah kami peserta Pengabdian Masyarakat (PKM), karena pesertanya adalah para santri dengan usia masih muda perlu kedepannya adalah pembinaan kearah karakter dan moral supaya menjadi pribadi yang kuat dengan tidak terpengaruh pergaulan-pergaulan tidak baik diluaran, yaitu perlu diberikan materi tentang bahaya narkotika dan kenakalan remaja, serta kerjasama dengan yayasan agar dapat mewujudkan perpustakaan dengan mengumpulkan buku-buku bekas dan baru untuk santriwan santriwati untuk bisa lebih mudah mengakses pengetahuan lebih banyak dan dapat diterapkan dalam kehidupan seharihari.

\section{DAFTAR PUSTAKA}

Abdullah, M. Ma'ruf (ed), Manajemen Bisnis Syariah, Yogyakarta: Aswaja Pressindo, 2014.

Al-Qur'an dan Terjemahnya, Departemen Agama Republik Indonesia, Semarang: Toha Putra, 1989.

As-Sabatin, Yusuf (ed), Bisnis Islami dan Kritik atas Praktik Bisnis Ala Kapitalis, Bogor: Al-Azhar Press, 2011.

Muhammad Syafi'I Antonio, Bank Syariah Bisnis dan Paraktek, Gema Insani, 2001.

Abd, Shomad, Prinsip Syariah Dalam Hukum Indonesia, Bandung, Prenada Media Group, 2010.

Hakim, Lukman, Prinsip-Prinsip Ekonomi Islam, Jakarta: Erlangga, 2012.

Hambal Imam Ahmad bin, Bab Musnad Abu Hurairah Juz II, Mesir: Muassasah AlQurtuba, tt. Harahap, M. Yahya, Hukum Perseroan Terbatas, Jakarta: Sinar Grafika, 2011. 
Loyalitas Kreativitas

Aldi Masyarakat Kreatif
P-ISSN 2722-2101, E-ISSN 2722-4201

Program Studi Ekonomi Manajemen Universitas Pamulang Jurnal LOKABMAS Kreatif Vol. 01, No. 03, Hal. 87-96 Email:jurnalkreatif.manajemen@gmail.com
Januari, Moh. Fauzan, Pengantar Hukum Islam dan Pranata Sosial, Bandung: Pustaka Setia, 2013. Karim, Adiwarman, Ekonomi Mikro Islam, Jakarta: Rajawali Press, 2011.

Qaradhawy, Yusuf, Halal dan Haram, Jakarta:Robbani Press, 2000.

Majalah/Artikel Edaran Hizbut Tahrir Indonesia, Kegoncangan Pasar Modal di Barat, November 1997.

AM Irfanudin, D Sunardi, R Sari, I Imbron, N Nariah. (2020). PERAN SEO

DALAM MENINGKATKAN

RELIABILITAS PEMASARAN PRODUK VIA MEDIA ONLINE PADA FORUM MUSLIMAH DEPOK. Dedikasi PKM, 1(1)

Pasaribu, V. L. D., Susanti, F., \& Hartuti, E. T. K. (2019). Memotivasi Siswa dan Siswi SMK Letris Indonesia di Dalam Menentukan Pilihan Untuk Melanjutkan Pendidikan Atau Bekerja Setelah Lulus Sekolah. Jurnal Pengabdian Dharma Laksana, 1(2), 161-172.

Pasaribu, V. L. D., Elburdah, R. P., Sudarso, E., \& Fauziah, G. (2020). PENGGUNAAN MANAJEMEN WAKTU TERHADAP PENINGKATAN PRESTASI BELAJAR DI SMP ARAISIYAH. Jurnal ABDIMAS Tri Dharma Manajemen, 1(1).

Pasaribu, V. L. D., Agrasadya, A., Shabrina, N., \& Krisnaldy, K. (2020). MENJADI ENTERPRENEUR MUDA YANG MEMILIKI JIWA LEADERSHIP UNTUK MENGHADAPI MASA DEPAN. Abdi Laksana, 1(1).

Pasaribu, V. L. D., Sulaiman, S., Sutiman, S., Thaharudin, T., \& Purnomo, B. Y. (2020). PENGENALAN LETAK POSYANDU TERDEKAT DIKELURAHAN PISANGAN DENGAN MANAJEMEN PEMASARAN REVOLUSI 4.0 UNTUK MENINGKATKAN PENGETAHUAN MASYARAKAT LETAK DAN FUNGSI POSYANDU TERDEKAT PADA
KELURAHAN PISANGAN. DEDIKASI PKM, 1(1), 105-110.

Priadi, A., Pasaribu, V. L. D., Virby, S., Sairin, S., \& Wardani, W. G. (2020). PENGUATAN EKONOMI KREATIF BERBASIS SUMBER DAYA DESA DIKELURAHAN REMPOA. Abdi Laksana, 1(3), 356-358.

Internet http://en.wikipedia.org/wiki/Jointstock_company
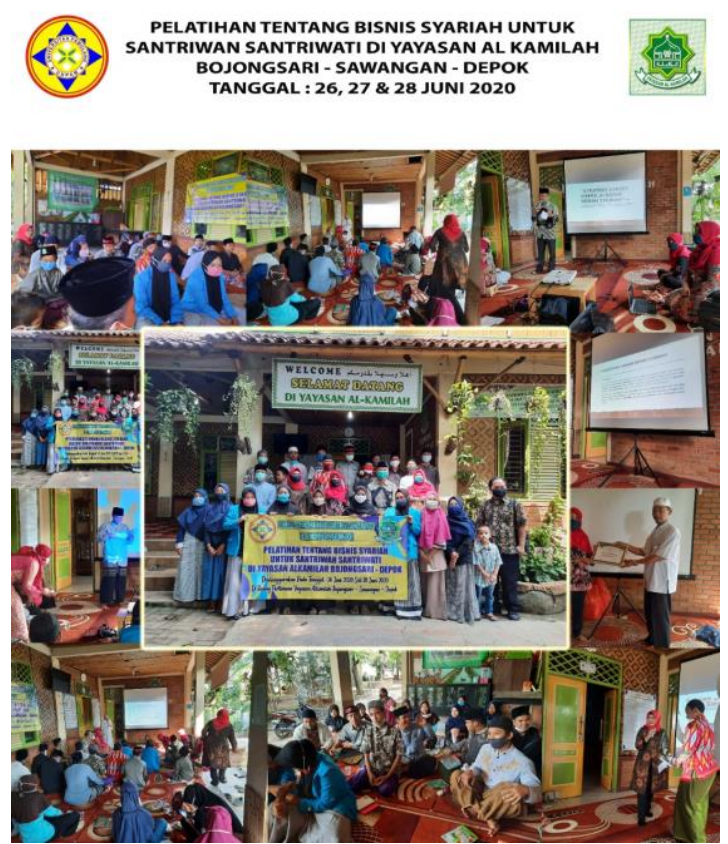
Loyalitas Kreativitas

Aldi Masyarakat Kreatif
P-ISSN 2722-2101, E-ISSN 2722-4201

Program Studi Ekonomi Manajemen Universitas Pamulang Jurnal LOKABMAS Kreatif Vol. 01, No. 03, Hal. 87-96 Email:jurnalkreatif.manajemen@gmail.com

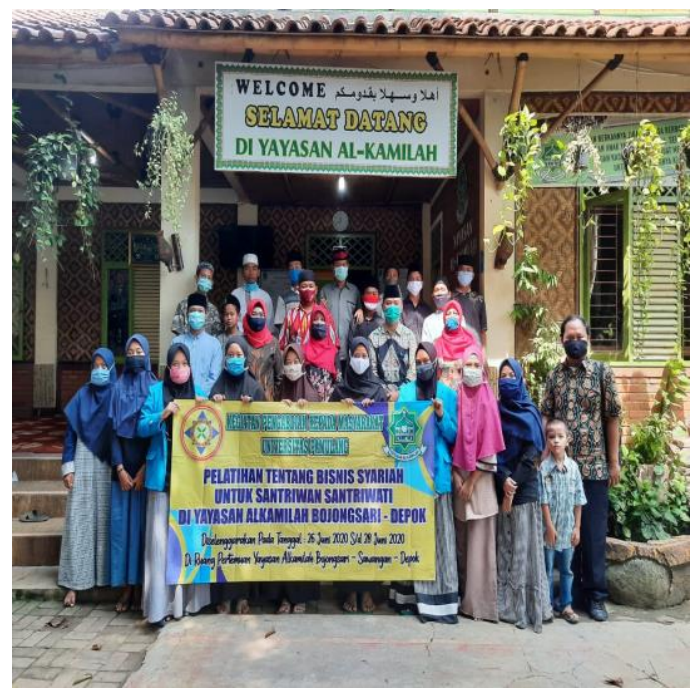

